\title{
Short note: new record of thrips (Insecta: Thysanoptera) on karuk plants (Piper sarmentosum) in indonesia
}

\author{
Vani Nur Oktaviany Subagyo ${ }^{1}$ and Tri Lestari M ardiningsih ${ }^{2}$ \\ ${ }^{1}$ Zoology Division, B iology Research Center, Indonesian Institute of Sciences, Jalan Raya J akarta-Bogor KM 46 Cibinong, Indonesia, \\ 16911 \\ ${ }^{2}$ Indonesian Spices and M edicinal Crops R esearch Institute, Jalan Tentara Pelajar 3, Bogor, Indonesia, 16111
}

\begin{abstract}
Thrips were reported as one of the pests of karuk (Piper sarmentosum) in the Garden of M edical Scientific Tourism, Indonesian Spice and M edicinal Crops Research Institute (ISM CRI). Thrips attack was known for the first time in A pril 2016 with moderate intensity. Affected leaves become wavy, rolled, and stiff then the leaves will dry up and wither. Morphology identification showed that Liothrips vaneeckei (Thysanopters: Phlaeothripidae) as the causal agent infested on karuk. This is the first report of $L$. vaneeckei in Indonesia.
\end{abstract}

Karuk plants (Piper sarmentosum) is a medicinal plant that belongs to the family of Piperaceae [1]. The leaves and the roots are usually taken as medicine such as shedding the mucus, reducing the symptoms of asthma, helping to urinate, reducing the pain of the stomachache, etc. [2]. Many benefits can be obtained from karuk but many challenges are faced in cultivating it, one of them is the attack of thrips (Insecta: Thysanoptera). Thrips attack on karuk at ISMCRI was known for the first time in April 2016, where 36 karuk plots were attacked with moderate intensity (wavy leaves, rolled, and stiff). However, the attack was not reported as a virus vector on plants.

In December 2016, a low attack of thrips was detected in several rolled leaves. The attack then increased in January 2017, in which 30 clumps were attacked in low to moderate intensity. On one of the tips, there were more than 30 eggs, 3 to 4 nymphs, and 10 to 11 imago. The eggs are $0.2 \times 0.44 \mathrm{~mm}$, white and yellowish that becoming darker until they hatched into larva (Fig. 1a). They were scattered on the upper surface of leaves; sometimes in the rolled off the attacked leaves. Larva turns to imago after prepupa and pupa stages [3]. The first stadia of the thrips are transparent with red ocelli and dark lines along the right and left part of the body. It is $0.2 \mathrm{~mm}$ in width and $0.7 \mathrm{~mm}$ in length (Fig. 1b). The second instars are yellow with brown and dark brown segments in the abdomen (Fig. 1c). Head, prothorax, and the last few segments of the abdomen that becomes pupa were brown with red creamy color $(0.44$ $\mathrm{mm}$ width and $1.5 \mathrm{~mm}$ length) (Fig. 1d). Pupae are usually found at the bottom surface of leaves, at the slit of plants (among sepals), or in the base of the leaves stem [3].

According to Lewis [3], the damage caused by thrips in particular areas of the crop is influenced by the roles and number of the population. However, the presence of thrips on the plant is not only as pests, because of several species of thrips are pollinators, predators, parasites, fungus-feeders, and some also induce leaf-galls [6-10]. Considering their various roles of thrips in the ecosystem, it is necessary to identify the species to determine appropriate management.

Therefore, ten individuals thrips on karuk at ISMCRI were collected and identified. The sample slides were made according to Mound \& Kibby [7], with protocol modified by Sartiami [11] and followed an identification procedure by Okajima [9]. Based on morphological characteristics, thrips species that attacked the karuk at ISMCRI were identified as Liothrips vaneeckei Priesner (Fig. 1-4) [9, 12].

Order: Thysanoptera

Suborder: Tubulifera

Family: Phlaeothripidae

Subfamily: Phlaeothripinae

Genus: Liothrips

Species: Liothrips veneeckei Priesner, 1920, 211; Priesner, 1928, 510-511; Kurosawa, 1968, 43; Mound \& Walker, 1986, 66 [9]

This genus belongs to the Liothrips lineage with more than 200 species in the world. Among the plant's

* Corresponding author: vani.oktaviany@gmail.com 
hosts of Liothrips genus are Moraceae, Lauraceae, Elaeocarpaceae, Piperaceae, Celastraceae, Symplocaceae, Gentianaceae, Elaeocarpaceae, Fagaceae, Umbelliferae, Combretaceae, Caprifoliaceae, and Cruciferae family. In the sub-tropical area, L. vaneeckei is known as a pest for Liliaceae and this species is commonly found under lily scales [9]. The origin of $L$. vaneeckei was unknown, but it was suspected to come from Eastern Asia [13]. L. vaneeckei spread in the Holoarctic area, New Zealand, Netherland, Austria, Italy,

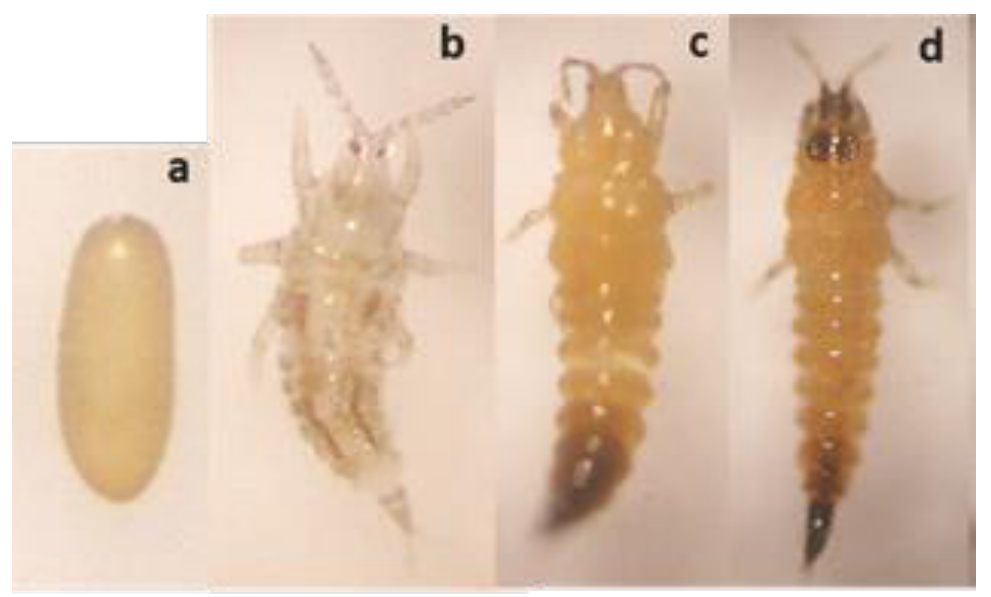

Fig. 1. D evelopment stages of L. vaneeckei: (a) egg stadia; (b) first instar stadia; (c) second instar stadia; (d) third instar stadia (prepupa) (Photo: M ardiningsih 2018)

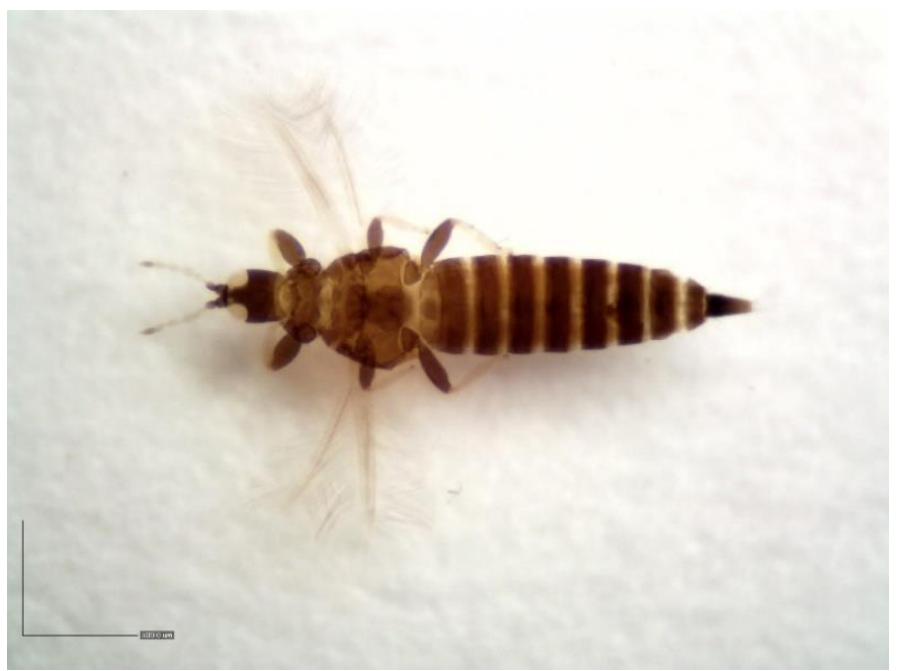

Fig. 2. L. vaneeckei (female macroptera): $2.5 \mathrm{~mm}$ body length with dark brown body color and all femora. 


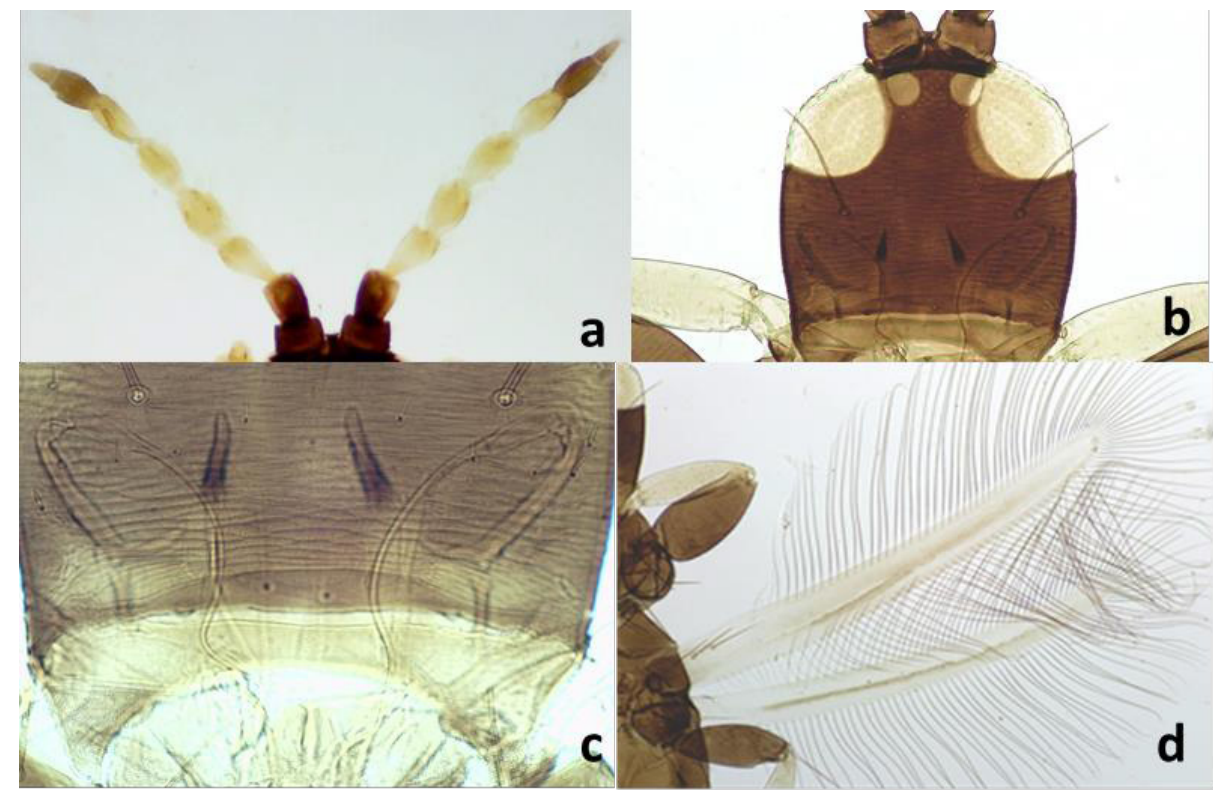

Fig. 3. L. vaneeckei: (a) antennal segment I-VIII; (b) the length of the head is 1.4 times of its width; (c) mouth-cone rather short; maxillary stylets reaching postocular setae, rather close together medially; and (d) the wings weakly shaded with brown and longitudinal dark lines in the middle (right side)
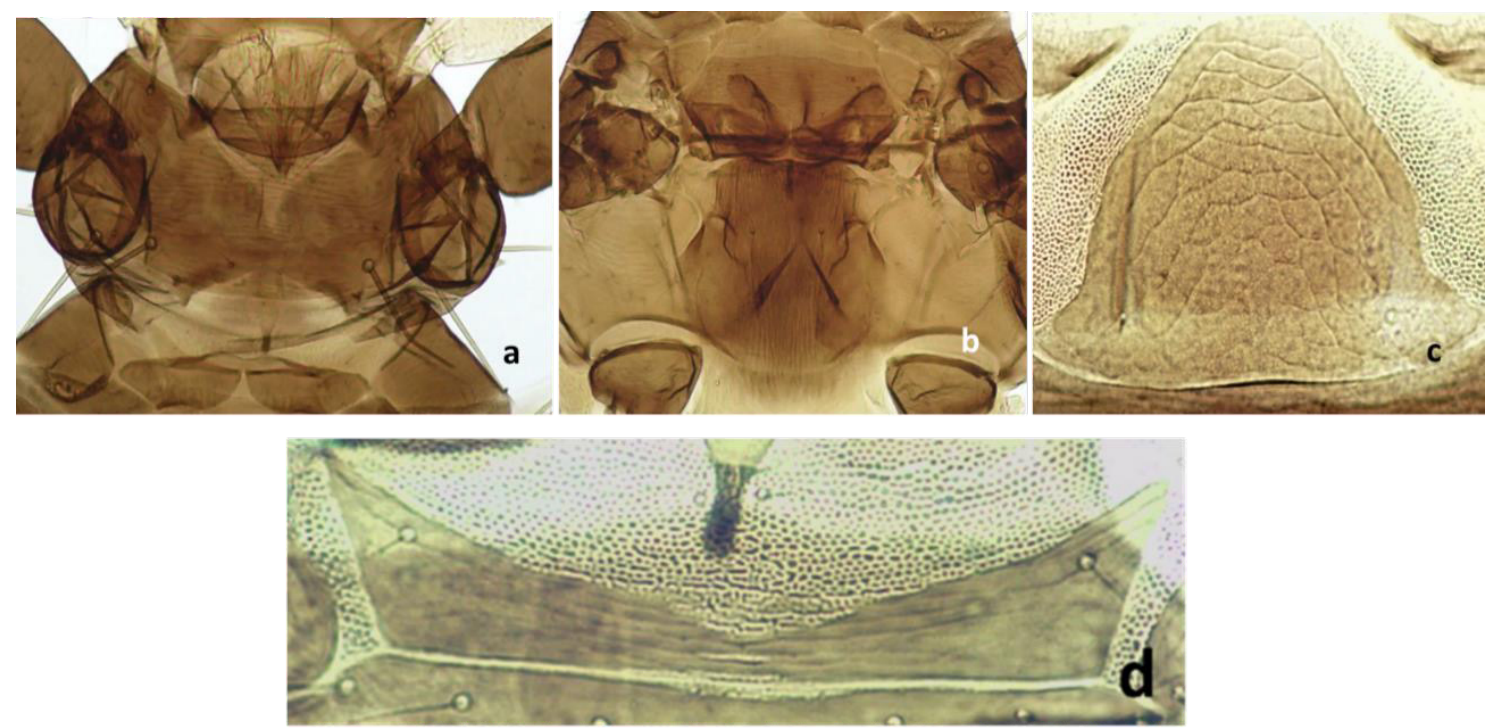

Fig. 4. L. vaneeckei: (a) the pronotum has five pairs of major setae narrowly blunt or almost pointed at apex, anteromalginal setae are well developed; (b) the metanotum has Iongitudinal reticulation; (c) triangular pelta; (d) mesopresternum are narrowly boatshaped

France, UK, Russia, Japan (Hokkaido, Honshu), and Sri Lanka $[9,14]$.

According to Bethke et al. [15], thrips are difficult to manage. The most effective strategy has only monitored its appearance. If it is suspected to damage the plant, the imago and larva can be monitored by hitting the branches or shake the leaves on a piece of light paper, tray, or small white cloth. The imago can also be monitored by hanging a sticky yellow trap on the host. If the attack occurred only to a few numbers of plants, pruning or removing the parts is the best way to take. If this method doesn't work due to the high thrips population, natural enemies such as predatory mites, predatory bugs, parasitoid, or entomopathogens can be the biological control agents and insecticides applied as the last option.

\section{Conclusion}

Morphology identification showed that Liothrips vaneeckei as causal agent infested on karuk in ISMCRI and this is the first report for the species in Indonesia. Further study (i.e. molecular study) needs to be proceeded to confirm the study results. The species is a phytophagous insect that induces leaf-galls on the host plants. Pest management can be supported by routine monitoring and natural enemies' development as the population control. 
We are also immensely grateful to Dr. Taufiq Purna Nugraha for his advice in documentation of the thrips specimen and Dr. Anik Budhi Dharmayanthi who will join us in working on the molecular identification of the collected samples.

\section{References}

1. T.C. Chieng, Z.B. Assim, B.A. Fasihuddin, MJAS 12, 1 (2008)

2. W. Ridtitid, W. Rattanaprom, P. Thaina, S. Chittrakarn, M. Sunbhanich, J. Ethnopharmacol., 61 (1998) DOI: 10.1016/50378-8741(98)00025-7

3. T. Lewis, Thrips: Their Biology, Ecology, and Economic Importance (A cademic Press, London, 1973) DOI: $10.1126 /$ science.184.4133.150-a

4. T.J. Izzo, S.M .J. Pinent, L.A. M ound, Fla. Entomol., 85 (2002) https://doi.org/10.1653/00154040(2002)085[0281:A DHTFE]2.0.C0;2

5. W.D.J. Kirk, The pest and vector from the west: Frankliniella ocidentalis. In Rita $M$ dan Laurence $M$, editor. Thrips and Tospoviruses. Proceedings of the 7th International Symposium on Thysanoptera; July 2-7, 2001; Reggio Calabria, Itali (CSIRO Entomology, Canberra, 2002).

6. T. Lewis, Pest thrips in perspective. in: Lewis, T. (ed.) Thrips as crop pests (CABI International, Wallingford, 1997)

7. L.A. Mound, G. Kibby, Thysanoptera an Identification Guide. The second edition. (CSIRO Entomology, Canberra, 1998)
8. L.A. Mound, D.J. Tree, OzThrips. (2013) [Online]. Access from htpp://www.ozthrips.org [Oktober 10, 2016].

9. S. Okajima, The Insect of Japan vol.2: The Suborder Tubulifera (Thysanoptera) (Touka Shobo Co. Ltd., Fukuoka, 2006)

10. V.N.O. Subagyo, P. Hidayat, A. Rauf, D. Sartiami, JEI 12, 2 (2015) DOI: 10.5994/jei.12.2.59

11. D. Sartiami, JIPI 13, 2 (2008)

12. T.N. A nanthakrishnan, A. Raman, Thrips and Gall Dynamics (Oxford and IBH Publishing Company, New Delhi, 1989)

13. University of California Liothrips vaneeckei (2012) [Online]. A ccess

from https://keys.lucidcentral.org/keys/v3/thrips_of_calif ornia/identify-thrips/key/california-thysanoptera2012/M edia/H tml/browse_species/Liothrips_vaneec kei.htm [February 9, 2018].

14. R. Schopp, C.F. Doucette, Liothrips vaneeckei Preisner, a Recently Discovered Pest of Lily Bulbs (1932) [Online]. Access from http://researchgate.net/.../233579326_ _ L iothrips [December 28, 2016].

15. J.A. Bethke, S.H. Dreistadt, L.G. Varela, Thrips (2014) [Online]. Access from http://ipm.ucanr.edu/PM G/PEST N OTES/pn7429.ht \begin{tabular}{llll}
\hline $\mathrm{ml}$ & [February & 1, & $2018]$
\end{tabular} 